\title{
Refusal as Radical Care? Moving Beyond Modern Industrial Agriculture
}

\author{
Saurabh Arora ${ }^{1}$ Barbara Van Dyck ${ }^{2}$
}

Published online: 27 October 2021

(c) Society for International Development 2021

\begin{abstract}
In this contribution we approach the refusal of modern industrial agriculture, as an act of radical care. We begin by recognizing the unprecedented crises of biodiversity losses and climate disruptions, amidst widespread inequality in a global pandemic, which are linked with modern agricultural development. This development is underpinned by the objectification of 'nature' that is designed into strategies and technologies of extraction and control like chemical pesticides, synthetic fertilizers, hybrid seeds, genetic engineering and digitalization. Refusal of strategies and technologies of modern objectification, we argue, is an act of radical care that is geared towards nurturing alternatives grounded in the Earth's pluriverse.
\end{abstract}

Keywords Modernity $\cdot$ Coloniality $\cdot$ Objectification $\cdot$ Control $\cdot$ Agroecology $\cdot$ Decoloniality

Just under a decade ago, Louise O. Fresco, the current vice chair of the scientific group of the United Nations Food Security Summit (UNFSS) made this global claim: 'Our food is safer and our diets are more diverse than ever before; production methods are becoming increasingly sustainable, clean, and efficient; and we are constantly becoming better at protecting biodiversity'. ${ }^{1}$ It is interesting to contrast this with a report published in Science three years earlier, in which Butchart et al. (2010: 1164) concluded that 'the rate of biodiversity loss does not appear to be slowing' since 2002 when world leaders had committed to stem biodiversity decline.

The continuing destruction of biodiversity has been highlighted by many reports in recent years. For example, at least $30 \%$ of the world's tree species are now reported to be threatened with extinction (BGCI 2021). Other estimates indicate that $40 \%$ of the world's insect species may be extinct in a few decades (Sánchez-Bayo and Wyckhuys 2019). Confirming these biodiversity losses, the Intergovernmental science-policy Platform on Biodiversity and Ecosystem Services (IPBES 2019) warns that roughly 1 million species of animals and plants are threatened with extinction and that the current rate at which species are going extinct

Saurabh Arora

s.arora@sussex.ac.uk

1 University of Sussex (UK), Brighton, UK

2 Centre for Agroecology, Water and Resilience, Coventry University (UK), Coventry, UK may be 'tens to hundreds of times' higher than the average rate over 'the last 10 million years'. It is not surprising then that most biologists now concur that the world is undergoing a mass extinction event, the first one in 66 million years (Wagner et al. 2021). Critically linked to these extinctions is modern industrial agriculture (Sánchez-Bayo and Wyckhuys 2019; Wagner et al. 2021), in which a whopping 6 million tonnes of toxic pesticides were used globally in 2019 (increasing from roughly 3 million tonnes in 1990) (FAOstat 2021). The same industrial agriculture driven by modern science and technology, received over USD 100 billion in annual subsidies from OECD countries alone (IPBES 2019).

Against this backdrop of biodiversity crises unfolding at the same time as worsening climate disruptions (IPCC 2021), and a COVID pandemic revealing the life-threatening effects of global inequality (Amnesty International 2021; Makau 2021), the UNFSS was organized for September 2021 with the ambition to 'feed hope for a better future'. However the hope it feeds is little more than a technocratic push for more modern 'science-driven innovations' like 'bioscience and related digital innovations' (von Braun et al. 2021a: 2).

Perhaps to fend off critique from civil society organizations and social movements like La Via Campesina, the UNFSS' scientific group also talks about 'traditional food system knowledge' and makes a call to strengthen 'research

\footnotetext{
${ }^{1}$ https://www.project-syndicate.org/commentary/how-technologi cal-progress-can-help-to-feed-the-world-by-louise-o--fresco?, emphasis added, accessed 24 September 2021.

${ }^{2}$ https://www.un.org/press/en/2021/sgsm20899.doc.htm.
} 
cooperation between science communities and indigenous peoples' knowledge communities' (von Braun et al. 2021a: 2). However, the latter communities are approached through the lens of 'multi-stakeholderism' which denies that they differ from a multi-national corporation or a nation-state (Canfield et al. 2021). Entirely missing thus is a discussion of how this multi-stakeholder table is structured unequally by five centuries of colonial curtailing of multiple 'indigenous' cultures and their intercultural relations, in the process of developing modern societies (Wolfe 2006; Arora and Stirling 2021). In the 420-page Science Reader produced by the scientific group of the UNFSS and its partners (von Braun et al. 2021b), colonialism is invoked briefly as a driver of inequality that marginalizes 'Indigenous People', but the ways in which it has pervasively structured the modern world and its techno-scientific pathways is left out of the picture.

\section{Colonial Designs of Modernity}

The Mexican philosopher Enrique Dussel (1993) is one among many southern scholars who argue that colonial pillage and genocidal violence since 1492 were central in giving 'birth' to the modern world. For example, it is through such pillage of an estimated $£ 9.2$ trillion (equivalent to $\$ 45$ trillion today) between 1765 and 1938 (Patnaik 2018), that India's share of the world economy shrank from pre-colonial 24-27\% to just 3-4\% in 1947 (Mukherjee 2010). Alongside pillage around the world, European colonialism enslaved and indentured millions to labour on monocultural plantations and mines (Manjapra 2020); appropriated and deforested 'indigenous' lands (Saravanan 2018); controlled 'traditional' governance processes (Mamdani 1996); destroyed diverse knowledge traditions (de Sousa Santos 2007); extended heterosexual patriarchy (Lugones 2007); and much more besides, in order to realize the modern world (Bayly 2004). Eurocentric framings routinely obscure this colonial constitution of modernity (Bhambra 2007), since Max Weber's (1930 [2001]) classic thesis. Situating the 'universal rationality' of emancipation at its heart, Eurocentrism attaches modernity to industrial progress based on science and technology and to bureaucratic and juridical institutions that protect the rights of the individual 'man'.

Such claims to rationality were argued to be little more than hypocrisies, by many anticolonial movements and intellectuals, at least since the start of the twentieth century $(\mathrm{Du}$ Bois 1903; Gandhi 1909; Césaire 1950; Fanon 1961; Head 1974). Modern claims were seen as hiding in their folds the multiple injustices of colonial dispossession and racism. Ongoing forms of dispossession and institutional racism in modern societies are once again foregrounded by movements like Black Lives Matter, Niyamgiri, No Dakota Access Pipeline, Rhodes Must Fall, Alliance for Food Sovereignty in
Africa, and Brazilian movements of Quilombos and Landless Workers.

Far from being universal, thus, modern progress and rights are revealed as selective, designed to serve those who are projected as 'superior' through colonialism, on the bases of race, nation, religion, class and gender (Quijano 2000; Lugones 2007). This is again plain to see in the "vaccine apartheid' that is unfolding to tackle the COVID pandemic (Byanyima 2021; Amnesty International 2021). Modern structures of power associated with racism, nationalism, Islamophobia and classism may be approached as constituting ongoing coloniality (Quijano 2000). Intersecting with different cultures of sexism or patriarchy (Crenshaw 1991; Lugones 2007), coloniality lies at the heart of alternative modernities around the world (Gaonkar 2001). It is these modernities that are now claimed to be transforming themselves towards climate resilience through setting net zero targets (Kothari 2021). But how any resilience can be realized without dismantling the structures of patriarchal coloniality remains unclear.

Patriarchal coloniality shapes modern ambitions of supremacy and control (Shiva 1988; Plumwood 1993). These ambitions underpin relations with 'nature' that is constructed as a fictitious realm of objects lacking agency beyond predictable mechanisms (Latour 1993). This objectification paves the way for approaching 'nature' primarily as a reservoir of resources that can be extracted without restraint, through the deployment of modern science and technology. The same objectification affords a callous lack of concern for the toxic chemical trails of resource extraction, which damage soils, rivers, lakes, springs, mountains, valleys, forests, and the plants and animals who live there (Merchant 1980; Arora et al. 2020). In modern industrial agriculture promoted through the 'Green Revolution' (Sharma 2019), objectification has enabled the development of irrigation technologies for unbridled groundwater extraction and of high-yielding varieties for treating living soils merely as containers for growing monocultures.

At the same time, nature's objectification makes the development of toxic technologies an innocent act rather than a crime (Serres 1995). This presumed innocence continues to be enacted in modern industrial agriculture through chemical pesticides and synthetic fertilizers, as part of new Green Revolutions and associated interventions including 'sustainable intensification' and 'climate-smart agriculture' (FAO 2010; Pretty et al. 2011; AGRA 2012). Green Revolutions have been promoted by states, philanthropies and corporations during the last six decades, while the toxic effects of their 'intensification' technologies have been amply clear, at least since the publication of Rachel Carson's Silent Spring (1962).

In general, these extractive toxic relations are justified in the name of eradicating hunger and poverty, as if modern 
industrial agriculture is the only possible way forward. This singular justification obscures and marginalizes diverse agroecological alternatives to the 'global' promotion of modern industrial agriculture that continues a model of agricultural development put in place during colonialism. ${ }^{3}$ To apprehend the coloniality of this agricultural modernization strategy, it is useful to once again turn to its constituting processes associated with objectification of 'nature'.

Objectification erects a categorical border between a singular 'nature' of nonhuman objects and multiple cultures of human subjects (Latour 1993; Arora et al. 2020). This bordering helps purify modern 'natural' science as objective, something that can be promoted as devoid of any cultural influences. In sharp contrast, 'indigenous', peasant or 'traditional' knowledges are seen as situated in specific cultures and thereby 'inferiorized' as partial and local (Agrawal 1995). For example, soil scientists and agronomists understand soil quality to be a function of levels of available nitrogen, phosphorus, potassium, acidity and alkalinity (Li et al. 2016). In contrast, peasants may know the 'same' soil's fertility by carefully observing its texture, colour and smell. While peasants' soil knowledges may be considered as culturally valid (Mazzucato and Niemeijer 2000), only modern scientists are seen as producing objective knowledge of nature to offer insights that are universally valid and complete (Benjamin 2015; Arora 2019). It is well-documented how this objectifying imagination is extended around the world, through modernizing development that is built upon the derision and destruction of alternative ways of knowing (Sachs 1992; Escobar 1995; Agrawal 1995).

The same imagination of modernity's presumed superiority now lies behind the UNFSS promotion of 'science-driven innovations' (von Braun et al. 2021a: 2), while appearing to be inclusive of 'traditional' and 'indigenous' knowledge. This inclusive facade fails to convince, as no specific indigenous traditions of agriculture are promoted by the UNFSS, despite the fact that more than 7000 languages and many associated ways of knowing continue to survive in the world. Diverse agroecological practices are still associated with these ways of knowing. They are largely ignored in official UNFSS processes, ${ }^{4}$ or assimilated into a technological innovation strategy focused on 'precision farming, Big Data, biotechnology, artificial intelligence, and other investor-friendly solutions'.5

\footnotetext{
3 https://www.scientificamerican.com/article/agroecology-is-thesolution-to-world-hunger/, accessed 22 September 2021.

${ }^{4} \mathrm{https}$ ///thecounter.org/united-nations-summit-protest-corporatio ns-sustainable-future-global-food-systems/ accessed 24 September 2021.; https://www.scientificamerican.com/article/agroecology-isthe-solution-to-world-hunger/ accessed 22 September 2021.

5 https://agroecologyresearchaction.org/peoplesknowledge/ accessed 24 September 2021
}

The innovations that are explicitly favoured by UNFSS are thus based in modern techno-sciences such as bioscience and digitalization. In promoting these technologies, the UNFSS appears to be supporting the agenda of big agrocorporations. A former chief technology officer at Monsanto (now Bayer), Robert Fraley, had already claimed a few years ago that the 'next green revolution will supercharge the tools of the old one' (Folger 2014). If the old Green Revolution relied on extraction through conventional high-yielding and hybrid varieties, the new one will 'supercharge' this process through genetic modification and large-scale extraction and repackaging of data. The extractivist coloniality at play here is once again underpinned by objectification of nature, and associated ambitions to control (Arora et al. 2020). Such control is imagined as achieving only what is intended, through a techno-scientific intervention, just like the flicking of a switch is expected to turn on an electric light (Stirling and Scoones 2020), without an accompanying spark or an electric shock.

A prominent 'supercharging' technology underpinning ambitions of the 'next Green Revolution' is genetic modification based on CRISPR-Cas9 (Doudna and Sternberg 2017). This technology is widely imagined as a pair of scissors that can cut a DNA molecule at any desired point, ostensibly to produce only the changes intended by biotechnologists, without any unwanted effects (Sirinathsinghji 2019). This control is already reported to be a fallacy. Many 'unintended' effects are now associated with the application of CRISPR-Cas9, including genetic modification in 'off-target species' and 'editing nucleases that induce double-stranded DNA breaks' in on-target species (Sirinathsinghji 2019: 2). ${ }^{6}$ Such possible harms can all be claimed to be 'unintended', largely because the uncertainties associated with such technologies are suppressed in the first place (Arora 2019; Stirling and Scoones 2020). These uncertainties are not simply knowledge gaps that can be reduced through further research, but rather they are ubiquitous across all kinds of knowledge that is claimed to be objective and actions presented as based on evidence. Embracing uncertainties associated with modern science and technology thus means challenging the assumption of supremacist control, in order to instead cultivate humility (Arora 2019). Such humility can help limit modernity's dominating influence in shaping a singular way ahead for agricultural production, and to sustain and grow spaces for diverse ways of knowing beyond the modern world's coloniality of extractive toxicity and supremacist ambitions of control.

\footnotetext{
${ }^{6}$ Growing lists of scientific reports of unexpected outcomes of gene editing on plant genomes can be consulted through https://gmwatch. org/en/news/latest-news/19499 and https://www.testbiotech.org/en accessed 24 September 2021.
} 


\section{Refusal as Radical Care}

In a spirit of sustaining and growing diverse ways of knowing that Indigenous Peoples practice, some scholars, peasantled social movements and other civil society organizations have embraced refusal, by saying no to participation in the UNFSS. This summit is considered to be rooted in alliances between multinational corporations, large philanthropies, and powerful governments, with their 'extractivist development model centered on corporate control of resources, policy debates, and regulatory processes' (Canfield et al. 2021). ${ }^{7}$ To embrace refusal is to talk back to these alliances and affirm diverse people's sovereignty. It is a way to say 'enough' (Simpson 2007: 78).

Refusal, as Ashanté Reese (2019) notes, is an 'ethic and practice of care' from which to produce 'other arrangements of the possible'. Refusal is at once a 'movement of exit and process of invention' (Weeks 2005: 100). It opens up possibilities within which to construct alternatives. Refusal resonates with recent work by movements like Black Lives Matter on abolition and mutual aid (Welch 2021). For example, identifying parallels between modern industrial agrifood systems and the prison-industrial complex that inflicts violence on black and brown bodies, Montenegro de Wit (2021) highlights possibilities of dismantling oppressive structures of racist coloniality through resistance while cultivating alternative relationships and practices that affirm life. Indeed, it is the building of alternatives based on values like mutual aid and solidarity that is seen as helping to dismantle entrenched structures of oppression (Welch 2021).

Peasant movements' refusal of some modern machinery, genetically modified crops or digital technologies, is not just political resistance against their further marginalization through modernization-it is crucially also an embrace of the possibilities of plural agroecological practices (van Dyck et al. 2021). Rather than seeing refusal as an aberration that rejects industrial progress and promised prosperity (Shange 2019), it should be recognized as 'unobjectionable an act as the [better funded] countervailing pressure to accept' (Van Dyck et al. 2021). Situating refusal in the context of coloniality underpinning modern industrial agriculture that enacts extractive toxicity and supremacist ambitions to control, helps to appreciate why some smallholders' and landless workers' refuse 'sustainable intensification' and 'smart farming' based on artificial intelligence, big-data, and gene editing. Based on a recognition of historical damage wrought by coloniality, such refusal may be approached as an act of radical care (Charles 2020).

Campaigns against genetically modified organisms by small farmers from Brazil to the Philippines, from the
UK to India, including the burning of GMO seeds and the destruction of field trials are probably the most confrontational forms of such refusal. But the practice of refusal has arguably been widespread throughout the history of modernity (Chaveau et al. 1999; Pérez-Vitoria 2020). For example, since the 1970s, the Nasa people (Pueblo Nasa) in Cauca (Colombia) have occupied haciendas, replaced sugarcane monocultures with diverse agroecologies and refused to provide free labour, all in order to 'liberate the earth' and restore ancestral lands. Similarly, in France, peasants have refused to accept their dispossession over decades, including the recent refusal of electronic identification of sheep through microchips. Shared by movements of refusal, around the world, is the adoption of alternative directions in which to move forward by saying: 'we refuse to continue on this way' (McGrahanan 2016: 320). Thus, movements of refusal not only embrace a politics of resistance for selfdetermination, but also seem to foreground the practice of collective radical care.

The term 'radical' comes from the Latin radix, or 'root'. It is through this emphasis on root that we want to explore embodiments of radical care. For us, the term radical points to two connotations of 'roots'. First, radical addresses roots in the coloniality that has marginalized and destroyed 'inferiorized' people's ways of living, in developing modern worlds (Arora and Stirling 2020). The caring that stems from this aspect of the 'radical' is egalitarian mutualism, directed simultaneously towards oneself and towards one's relations of nurturing, with humans and nonhumans, which are required for living and growing (Penniman 2020). Second, radical points to the search for collective decolonial histories, that can serve as anchors for 'other-thanmodern' worlds in the present and future (Estes 2018). A purpose of this search is to support marginalized people's relational capacities to produce knowledge that is at once 'natural' and cultural (Haraway 1991). Caring in this radical way, points to the pluralization of ways of relating with neglected or vulnerable others in societies and ecologies, which diverge from the colonial relations of extractive toxicity and supremacist control driving the modern world.

It is important to distinguish such radical care from carework in its many exploitative forms that have become more pronounced in the COVID-19 pandemic (Chatzidakis et al. 2020; Welch 2021). Care can for example be 'used to coerce subjects into new forms of surveillance and unpaid labour, to make up for institutional neglect, and even to position some groups against others, determining who is worthy of care and who is not' (Hobart and Kneese 2020: 2). Similarly, attempts to assimilate agroecology based ostensibly on care for 'nature', into modern agriculture by 'stuffing

\footnotetext{
7 https://www.foodsystems4people.org accessed 24 September 2021.
} 
agroecology in the innovation box ${ }^{8}$ does not challenge extractive relations or domination of smallholder farmers and other 'inferiorized' people. ${ }^{9}$

Unlike such forms of coercive care, radical care prioritizes relations over the categories that divide people into groups (Arora et al. 2020). It recognizes that nothing comes without its world of surrounding relations that are at once social and ecological (Hobart and Kneese 2020; de la Bellacasa 2017). Radical care foregrounds this 'relationality' (Latour 2005), across practices of all kinds from tilling the land to trading in an online marketplace, to lay bare the modern fallacy that cultures are separate from nature (Arora et al. 2020). Going beyond verbal recognition of 'radical relationality' (Escobar 2020; Sultana 2021), embodiments of radical care practice egalitarianism that sustains the cultural difference of others (Arora et al. 2020). This means that radical care in practice seeks the survival of the alterity of cultural forms in all their diversity (Escobar 2006), but actively resists pressures to order differences hierarchically. Therefore, radical care is geared towards achieving 'equality-indifference' (Escobar 2006: 120), and comprehensive justice for plural ways of relating that have been 'inferiorized' by coloniality.

Such quests for social justice and equality, however, are incomplete if 'nature' for the production of truth, is considered accessible only to modern science. The latter is found in technocratic approaches that turn agroecology into yet another tool in the extractive toolbox of modern industrial agriculture (Giraldo and Rosset 2018). By building diverse agroecologies in communities and territories, by articulating radical approaches to food justice, food sovereignty and sustaining other ways of living in the pluriverse, people practice concrete ways of healing socioecologies harmed by toxic and extractive relations of modernity. Rebecca Clausen (2007) for example shows how agroecology practices in Cuba alter complex relations including soil understandings, land and food distribution patterns and labour relations.

Radical care indeed initiates processes of healing to undo the damage wrought on alternative ways of knowing by coloniality (Quijano 2000; Sultana 2021). It foregrounds the rich diversity of ways of knowing still surviving in the many worlds of the earth's pluriverse (de la Cadena and Blaser

\footnotetext{
${ }^{8}$ Anderson, Colin. 2018. The Politics of Co-optation in the Struggle for Just Sustainability: Stuffing Agroecology into the Innovation Box. Workshop at laboratoire agriculture urbaine http://www.agroecolog ynow.com/agroecology-innovation-talk/accessed 30 September 2021.

${ }^{9}$ Civil society organizations and their allies have referred to Agroecology 'Lite' or 'junk' agroecology to name various pressures to assimilate agroecology into modern agriculture https://foodfirst.org/ agroecology-lite-cooptation-and-resistance-in-the-global-north/ or https://www.foei.org/features/junk-agroecology-corporations-co-opting-peoples-solutions-food-crisis-covid-19 accessed 30 September 2021
}

2018; Arora and Stirling 2020). The pluriverse does not involve a recognition of plural 'natures' (that are each bordered from their culture), but rather observing the presence of multiple socioecologies spanning nature-culture divides. These socioecologies are constituted by a rich diversity of ways of relating beyond modern extractivism and control. As noted by Arora and Stirling (2021), pluriversal ways of relating include connecting with selected plants and animals as persons (Guzmán-Gallegos 2021), with tropical forests that are considered sacred and powerful (Maarif 2015), and with hospitality and wonder towards people with ways of knowing and living that are different from one's own (Hafiz 2020). Such diversity in patterns of relations underpinning multiple socioecologies, means that there is never just one radically caring agroecology that offers an alternative to modern industrial agriculture. Alternatives are always many, within and between places, at least so long as there is a pluriverse on earth.

\section{Conclusions}

'It is easier to raise hands and declaim 'unintended consequences' than to get prior consent' appears to be the principle governing the UN Food System Summit's decisive rush for modern agriculture based on genetics and digitalization. It seems that the world at large is yet again being mobilized to offer a free hand to agro-industrial corporations and their institutional sponsors, to sell new knowledge and materials of biometrics, novel foods, animal face recognition, synthetized insecticides, or climate-smart crops. These technologies, based in the coloniality of extractive toxicity and ambitions to control underpinning modern industrial agriculture, are promoted as unleashing 'food systems transformations' that are necessary for sustainability (von Braun et al. 2021c). Yet the transformations they promise are little more than cosmetic techno-fixes, which leave untouched the (colonial) power structures that constitute modern agriculture.

Now this push for the latest modern sciences, technologies and innovations comes at a time when modernity's destructive consequences from catastrophic biodiversity losses to rampant climate disruptions have become difficult to deny and are increasingly framed as 'global' crises. Perhaps this is why the role of 'indigenous knowledge communities' is invoked, for purposes of legitimation and warding off critique from social movements and critical scholars alike. Crises after all, as the recent COVID pandemic shows, are also opportunities for those in power, to re-assert their supremacy as providers of solutions and drivers of ways forward, even if this re-assertion might now involve lip service to 'indigenous' and 'traditional' knowledges.

We have argued that refusal to participate in a Summit that fails to account for entrenched power, and the wider 
refusal to adopt modern technologies, is not just a countermovement against concentrated coloniality in the modern agro-industrial complex. It is not just resistance against extractive toxicity and supremacist control which destroy biological and cultural diversities. It is not just a rejection of attempts to continue the erasure, scraping, copying and stealing of land, knowledge and data from marginalized people and objectified 'nature'. It is not just opposition to the singularization of agricultural futures by techno-sciences that suppress uncertainties for narrow epistemological authority and widespread precarity. Refusal is also crucially about movements of radical care, which are oriented towards embracing alternatives to toxic technologies and controlling practices. Refusal as radical care thus is a practical strategy to nurture plural agroecological alternatives to modern industrial agriculture.

\section{References}

AGRA. 2012. Moving from strength to strength. Nairobi, Kenya: Alliance for a Green Revolution in Africa.

Agrawal, Arun. 1995. Dismantling the divide between indigenous and scientific knowledge. Development and Change 26 (3): 413-439. https://doi.org/10.1111/j.1467-7660.1995.tb00560.x.

Amnesty International. 2021. A double dose of inequality: Pharma companies and the COVID-19 vaccines crisis. London: Amnesty International.

Arora, Saurabh. 2019. Admitting uncertainty, transforming engagement: Towards caring practices for sustainability beyond climate change. Regional Environmental Change 19 (6): 1571-1584.

Arora, Saurabh and Andy Stirling. 2020. Don't save the world, embrace a pluriverse, STEPS Centre Blog, Brighton UK.

Arora, Saurabh, Barbara Van Dyck, Divya Sharma, and Andy Stirling. 2020. Control, care, and conviviality in the politics of technology for sustainability. Sustainability: Science, Practice and Policy 16 (1): 247-262.

Arora, Saurabh and Andy Stirling. 2021. Degrowth and the pluriverse: Continued coloniality or intercultural revolution, STEPS Centre Blog, Brighton UK.

Bayly, Christopher Alan. 2004. The Birth of the Modern World, 17801914: Global connections and comparisons. Oxford: Blackwell.

Benjamin, Ruha. 2015. The Emperor's New Genes: Science, Public Policy, and the Allure of Objectivity. The ANNALS of the American Academy of Political and Social Science 661 (1): 130-142.

BGCI. 2021. State of the World's Trees, Richmond, UK.

Bhambra, Gurminder. 2007. Rethinking Modernity: Postcolonialism and the Sociological Imagination. Berlin: Springer.

Butchart, Stuart H.M., Matt Walpole, Ben Collen, Arco Van Strien, Jörn. P.W. Scharlemann, Rosamunde E.A. Almond, Jonathan E.M. Baillie, et al. 2010. Global biodiversity: indicators of recent declines. Science 328 (5982): 1164-1168.

Byanyima, Winnie. 2021. A global vaccine apartheid is unfolding. People's lives must come before profit. The Guardian, 29 January. Accessed 18 Oct 2021.

Canfield, Matthew, Molly D. Anderson, and Philip McMichael. 2021. UN Food Systems Summit 2021: Dismantling Democracy and Resetting Corporate Control of Food Systems. Frontiers in Sustainable Food Systems 5: 103.

Carson, Rachel. 1962[2002]. Silent Spring. Houghton Mifflin Harcourt.

Césaire, Aimé. 1950[2001]. Discourse on colonialism. NYU Press.
Charles, Nicole. 2020. Suspicion and/as radical (Care) looking closer at vaccine hesitancy in postcolonial Barbados. Social Text 38 (1): 89-107.

Chatzidakis, Andreas, Jamie Hakim, Jo. Littler, Catherine Rottenberg, and Lynne Segal. 2020. From carewashing to radical care: The discursive explosions of care during Covid-19. Feminist Media Studies 20 (6): 889-895.

Chaveu, Jean-Pierre., Marie-Christine. Cormier-Salem, and Eric Mollard. 1999. L'innovation en agricuIture. Questions de méthodes et terrains d'observation. Paris: Editions de l'IRD.

Clausen, Rebecca. 2007. Healing the Rift: Metabolic Restoration in Cuban Agriculture. Monthly Review 51 (1): 40-52.

Crenshaw, Kimberly. 1991. Mapping the margins: Intersectionality, identity politics, and violence against women of color. Stanford Law Review 43 (6): 1241-1299.

De Sousa Santos, Boaventura. 2007. Beyond abyssal thinking: From global lines to ecologies of knowledges. Review (Fernand Braudel Center) XXX: 45-89.

Puig de la Bellacasa, Maria. 2017. Matters of care: Speculative ethics in more than human worlds, Minneapolis: University of Minnesota Press.

Cadena, Marisol de la, and Mario Blaser. (eds.) 2018. A World of Many Worlds. Durham: Duke University Press.

Montenegro de Wit, Maywa. 2021. What grows from a pandemic? Toward an abolitionist agroecology. The Journal of Peasant Studies 48 (1): 99-136.

Doudna, Jennifer A., and Samuel H. Sternberg. 2017. A Crack in Creation: Gene Editing and the Unthinkable Power to Control Evolution. Boston: Houghton Mifflin Harcourt.

Du Bois, W.E.B. 1903. The Souls of Black Folk. Salt Lake City: Project Gutenberg ebook.

Dussel, Enrique. 1993. Eurocentrism and Modernity (Introduction to Frankfurt Lectures). In The postmodernism debate in Latin America, vol. 20, ed. John Beverley and José Oviedo, 65-76. Durham: Duke University Press.

Escobar, Arturo. 1995. Encountering Development: The Making and Unmaking of the Third World. Princeton: Princeton University Press.

Escobar, Arturo. 2006. An Ecology of Difference: Equality and Conflict in a Glocalized World. Focaal 47: 120-137.

Escobar, Arturo. 2020. Pluriversal Politics: The Real and the Possible. Durham: Duke University Press.

Estes, Nick. 2018. Our History is the Future. London: Verso.

Fanon, Frantz. 1961. The Wretched of the Earth. New York: Grove.

FAO. 2010. "Climate-Smart" Agriculture: Policies, practices and financing for food security, adaptation and mitigation, Food and Agriculture Organization of the United Nations.

FAOstat. 2021. Pesticide Use (Dataset).

Folger, Tim. 2014. The Next Green Revolution. National Geographic Magazine. https://www.nationalgeographic.com/foodfeatures/ green-revolution/. Accessed 27 Sept 2021.

Gandhi, Mohandas Karamchand. 1909. Hind Swaraj and other writings. Cambridge: Cambridge University Press.

Gaonkar, Dilip. 2001. Alternative modernities. Durham: Duke University Press.

Giraldo, Omar Felipe, and Peter M. Rosset. 2018. Agroecology as a territory in dispute: Between institutionality and social movements. The Journal of Peasant Studies 45 (3): 545-564.

Guzmán-Gallegos, María A. 2021. Philippe Descola: Thinking with the achuar and the Runa in Amazonia. Ethnos 86 (1): 114-131.

Hafiz, Muneeb. 2020. Smashing the Imperial Frame: Race, Culture, (De)Coloniality. Theory, Culture \& Society 37 (1): 113-145.

Haraway, Donna. 1991. Simians, Cyborgs and Women: The Reinvention of Nature. Abingdon: Routledge.

Head, Bessie. 1974. A Question of Power. London: Penguin. 
Hobart, Hi'ilei Julia Kawehipuaakahaopilani, and Tamara Kneese. 2020. Radical Care: Survival Strategies for Uncertain Times. Social Text 38 (1): 1-16.

IPBES. 2019. Global assessment report on biodiversity and ecosystem services of the Intergovernmental Science-Policy Platform on Biodiversity and Ecosystem Services. E.S. Brondizio, J. Settele, S. Díaz, and H.T. Ngo (eds.). IPBES secretariat, Bonn, Germany: 1148. https://doi.org/10.5281/zenodo.3831673.

IPCC. 2021. Climate Change 2021: The Physical Science Basis (Summary for Policymakers). Intergovernmental Panel on Climate Change.

Kothari, Ashish. 2021. The 'net-zero' greenwash: Climate crisis and biodiversity loss are becoming impossible to ignore. Wall Street Magazine.

Latour, Bruno. 1993. We Have Never Been Modern. Cambridge: Harvard University Press.

Latour, Bruno. 2005. Reassembling the Social: An Introduction to Actor-Network Theory. Oxford: Oxford University Press.

Li, Ling, Tao Yang, Robert Redden, Weifeng He, and Xuxiao Zong. 2016. Soil Fertility Map for Food Legumes Production Areas in China. Scientific Reports 6 (1): 1-14.

Lugones, María. 2007. Heterosexualism and the colonial/modern gender system. Hypatia 22 (1): 186-219.

Maarif, S. 2015. Ammatoan Indigenous Religion and Forest Conservation. Worldviews 19: 144-160.

Makau, Winnie. 2021. The Impact of COVID-19 on the Growing North-South Divide, E-International Relations, 15 March, https:// www.e-ir.info/2021/03/15/the-impact-of-covid-19-on-the-growi ng-north-south-divide/. Accessed 25 Sept 2021.

Mamdani, Mahmood. 1996. Citizen and Subject: Contemporary Africa and the Legacy of Late Colonialism. Princeton: Princeton University Press.

Manjapra, Kris. 2020. Colonialism in Global Perspective. Cambridge: Cambridge University Press.

Mazzucato, Valentina, and David Niemeijer. 2000. The cultural economy of soil and water conservation: Market principles and social networks in Eastern Burkina Faso. Development and Change 31: 831-855.

McGranahan, Carole. 2016. Theorizing Refusal: An Introduction. Cultural Anthropology 31 (3): 319-325.

Merchant, Carolyn. 1980. The Death of Nature: Women. Ecology, and the Scientific Revolution, vol. 164. San Francisco: HarperCollins.

Mukherjee, Aditya. 2010. Empire: How colonial India made modern britain. Economic and Political Weekly 45 (50): 73-82.

Patnaik, Utsa. 2018. Revisiting the drain, or transfers from India to britain in the context of global diffusion of capitalism. In Agrarian and Other Histories-Essays for Binay Bhushan Chaudhuri, ed. Shubhra Chakrabarti and Utsa Patnaik. New Delhi: Tulika Press.

Penniman, Leah. 2020. To free ourselves we must feed ourselves. Agriculture and Human Values 37 (3): 521-522.

Pérez-Vitoria, Silvia. 2020. Technologie, technocratie et résistances paysannes. Ecologie Politique 2: 45-59.

Plumwood, Val. 1993. The politics of reason: Towards a feminist logic. Australasian Journal of Philosophy 71 (4): 436-462.

Pretty, Jules, Camilla Toulmin, and Stella Williams. 2011. Sustainable intensification in African agriculture. International Journal of Agricultural Sustainability 9 (1): 5-24.

Quijano, Anibal. 2000. Coloniality of power and eurocentrism in latin America. International Sociology 15 (2): 215-232.

Reese, Ashanté. 2019. Refusal as care. Anthropology News 60 (3): e135-e138.

Sachs, Wolfgang, ed. 1992. The development Dictionary: The Guide to Knowledge as Power. London: Zed Books.
Sánchez-Bayo, Francisco, and Kris A.G.. Wyckhuys. 2019. Worldwide decline of the entomofauna: A review of its drivers. Biological Conservation 232: 8-27.

Saravanan, Velayutham. 2018. Environmental History and the Tribals in Modern India. Singapore: Springer.

Serres, Michel. 1995. The Natural Contract. Ann Arbor: University of Michigan Press.

Shange, Savannah. 2019. Black Girl Ordinary: Flesh, Carcerality, and the Refusal of Ethnography. Transforming Anthropology 27 (1): 3-21.

Sharma, Divya. 2019. What is revolutionary about the Green Revolution. IDS Blog, 13 June, https://www.ids.ac.uk/opinions/whatis-revolutionary-about-the-green-revolution/. Accessed $27 \mathrm{Sept}$ 2021.

Shiva, Vandana. 1988. Staying Alive: Women, Ecology and Survival in India. New Delhi: Kali for women.

Simpson, Audra. 2007. On ethnographic refusal: Indigeneity, 'voice' and colonial citizenship. Junctures: The Journal for Thematic Dialogue 9: 67-80.

Sirinathsinghji, Eva. 2019. Transferring the Laboratory to the Wild: An Emerging Era of Environmental Genetic Engineering. Biosafety Briefing, Third World Network, November.

Stirling, Andy and Ian Scoones. 2020. COVID-19 and the futility of control in the modern world. Issues in Science and Technology XXXVI, no. 4: 25-27, Summer.

Sultana, Farhana. 2021. Progress report in Political ecology II: Conjunctures, crises, and critical publics. Progress in Human Geography. https://doi.org/10.1177/03091325211028665.

Van Dyck, Barbara, Anneleen Kenis, and Andy Stirling. 2021. The genetically modified organism shall not be refused? Talking back to the technosciences. Environment and Planning E: Nature and Space. https://doi.org/10.1177/25148486211042307.

von Braun, Joachim, Kaosar Afsana, Louise O. Fresco, and Mohamed Hassan. 2021a. Food systems: Seven priorities to end hunger and protect the planet. Nature Comment 597: 28-30.

von Braun, Joachim, Kaosar Afsana, Louise O. Fresco, and Mohamed Hassan. 2021b. Science and Innovations for Food Systems Transformation and Summit Actions. Papers by the Scientific Group and its partners in support of the UN Food Systems Summit, https://sc-fss2021.org/wp-content/uploads/2021/09/ScGroup_ Reader_UNFSS2021.pdf.

von Braun, Joachim, Kaosar Afsana, Louise O. Fresco, Mohamed Hassan, and Maximo Terero. 2021c. Food system concepts and definitions for science and political action. Nature Food. https://doi.org/ 10.1038/s43016-021-00361-2.

Wagner, David L., Eliza M. Grames, Matthew L. Forister, May R. Berenbaum, and David Stopak. 2021. Insect decline in the Anthropocene: Death by a thousand cuts. Proceedings of the National Academy of Sciences 118 (2): e2023989118.

Weber, Max. 1930 [2001]. The Protestant Ethic and the Spirit of Capitalism. London: Routledge.

Weeks, Kathi. 2005. The Refusal of Work as Demand and Perspective. In Resistance in practice. The philosophy of Antonio Negri, ed. T.S. Murphy and M. Abdul-Karim, 109-135. London: Pluto Press.

Welch, Adele. 2021. Root networks of radical care: Mutual aid in Minneapolis' abolitionist movement. Tapestries: Interwoven voices of local and global identities 10 (1): 3 .

Wolfe, Patrick. 2006. Settler colonialism and the elimination of the native. Journal of Genocide Research 8 (4): 387-409.

Publisher's Note Springer Nature remains neutral with regard to jurisdictional claims in published maps and institutional affiliations. 